\title{
Ichnofacies, Ichnocoenoses, and Ichnofabrics of Quaternary Shallow-Marine to Dunal Tropical Carbonates: A Model and Implications
}

H. Allen Curran

Smith College, acurran@smith.edu

Follow this and additional works at: https://scholarworks.smith.edu/geo_facpubs

Part of the Geology Commons

\section{Recommended Citation}

Curran, H. Allen, "Ichnofacies, Ichnocoenoses, and Ichnofabrics of Quaternary Shallow-Marine to Dunal Tropical Carbonates: A Model and Implications" (2007). Geosciences: Faculty Publications, Smith College, Northampton, MA.

https://scholarworks.smith.edu/geo_facpubs/68

This Book Chapter has been accepted for inclusion in Geosciences: Faculty Publications by an authorized administrator of Smith ScholarWorks. For more information, please contact scholarworks@smith.edu 
Proof version: Chap. 14 by H. A. Curran, in TRACE FOSSILS Concepts, Problems, Prospects, edited by William Miller III, Elsevier, Amsterdam, 2007, p. 232-247.

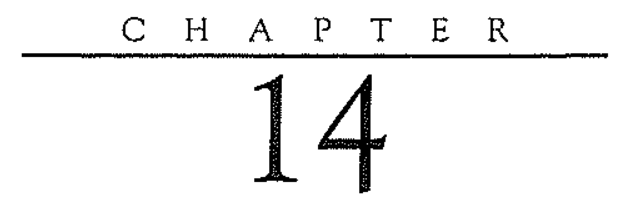

\title{
Ichnofacies, Ichnocoenoses, and Ichnofabrics of Quaternary Shallow-Marine to Dunal Tropical Carbonates: A Model and Implications
}

\author{
H. Allen Curran
}

SUMMARY: A model of five ichnocoenoses within the Skolithos and Psilonichnus ichnofacies characterizes the modern, Holocene, and Pleistocene coastalcarbonate depositional environments and limestones of the Bahamas, as well as the Miami Limestone of south Florida. The subtidal to intertidal ichnocoenoses of the Skolithos ichnofacies are dominated by tracemaking activities and trace fossils of callianassid shrimp, which can create distinctive and maximum ichnofabrics. Fossil Upogebia vasquezi burrows found in intertidal calcarenites and burrows of the trace fossil Psilonichnus upsilon, most common in beach backshore beds, have excellent potential as stratigraphic markers and can be used as indicators of past sea-level positions. The dunal ichnocoenosis exhibits a high ichno-diversity owing to the presence of arthropod-generated trace fossils and rhizomorphs, resulting from the activities of plants; trace fossils created by insects can be large and complex and can impart distinctive ichnofabrics to eolianites. Ichnologic studies of modern tropical carbonate environments and their rock-record equivalents have great potential for future development, and information from carbonates should be fully integrated with that of siliciclastics, with carbonates not viewed as a separate ichnologic subdiscipline.

\section{INTRODUCTION}

Modern tropical environments, especially rainforests and coral reefs, are noted for their high levels of biodiversity. It follows that modern and ancient tropical environments of carbonate-sediment deposition, with their diverse faunas and floras, should be expected to contain a rich record of ichnologic activity. The Bahama Archipelago and the south Florida region, including the Florida Keys, are internationally known as textbook examples for the study of limestone-producing environments. Many of these shallow-marine and terrestrial environments are well represented in the Quaternary rock record of the Bahama Islands (Curran and White, 1995) and south Florida (Randazzo and Halley, 1997). The Bahamas, south Florida, and other geologically similar areas around the globe, such as Bermuda, the Cayman Islands, the Yucatan coast of Mexico, coastal Belize, Pacific atolls, the Great Barrier Reef area of Australia, the Maldives, and the Seychelles, to name just a few (see Vacher and Quinn, 1997 for more island examples), are ideal natural laboratories for the study of physical and biogenic processes and their manifestation in Quaternary and older carbonate rock sequences. 
The purpose of this chapter is to present and discuss an integrated model for the ichnofacies, ichnocoenoses, and ichnofabrics represented by the modern tropical shallow-marine and coastal terrestrial environments and their analogous Quaternary rockunit equivalents that comprise the carbonate platforms and islands of the Bahama Archipelago and the south Florida region. This summary builds on a series of previous articles by the author, most notably Curran and White (1991,2001), Curran (1994), and Curran and Martin (2003), as well as other articles cited therein. The pioneering studies of biogenic structures in modern shallow-subtidal to intertidal environments in south Florida and the Bahamas by Shinn (1968) and Garrett (1977) and on Aldabra Atoll in the Seychelles by Farrow (1971) provide inspiration and an initial framework for the continued study of the ichnology of shallow marine to terrestrial carbonate environments throughout the geologic record.

It should be noted from the outset that the Bahama Archipelago and south Florida encompass a large geographic area (Fig. 14.1), and only selected parts have been studied in detail from the ichnologic perspective. Furthermore, this ichnologic model incorporates principally soft-sediment, endobenthic animal and plant traces. Borers and most track- and trailmaking organisms are excluded, not because of their absence, but rather owing to the present lack of sufficient information. Thus I consider this model and its implications to be work in progress, with much potential for addition and extension with future investigations. Given chapter length constraints and the structure of this volume, the key trace fossil forms are illustrated, but detailed descriptions are not given herein, as they can be found in the references cited above and/or to follow.

\section{ICHNOLOGY OF CARBONATE VS. SILICICLASTIC ENVIRONMENTS}

The ichnofacies, ichnocoenoses, and ichnofabrics discussed in this chapter occur in all-carbonate regimes with minimal siliciclastic influence. The importance of ichnology to the study of past and present carbonate environments is now well recognized, but the ichnology of carbonates remains understudied in comparison to that of siliciclastic settings. This is reflected in the contents of this volume, where only one other chapter (Knaust, Chapter 31) deals directly with a carbonates setting, although the chapter on stromatolites and the several chapters on borers and bioerosion undoubtedly

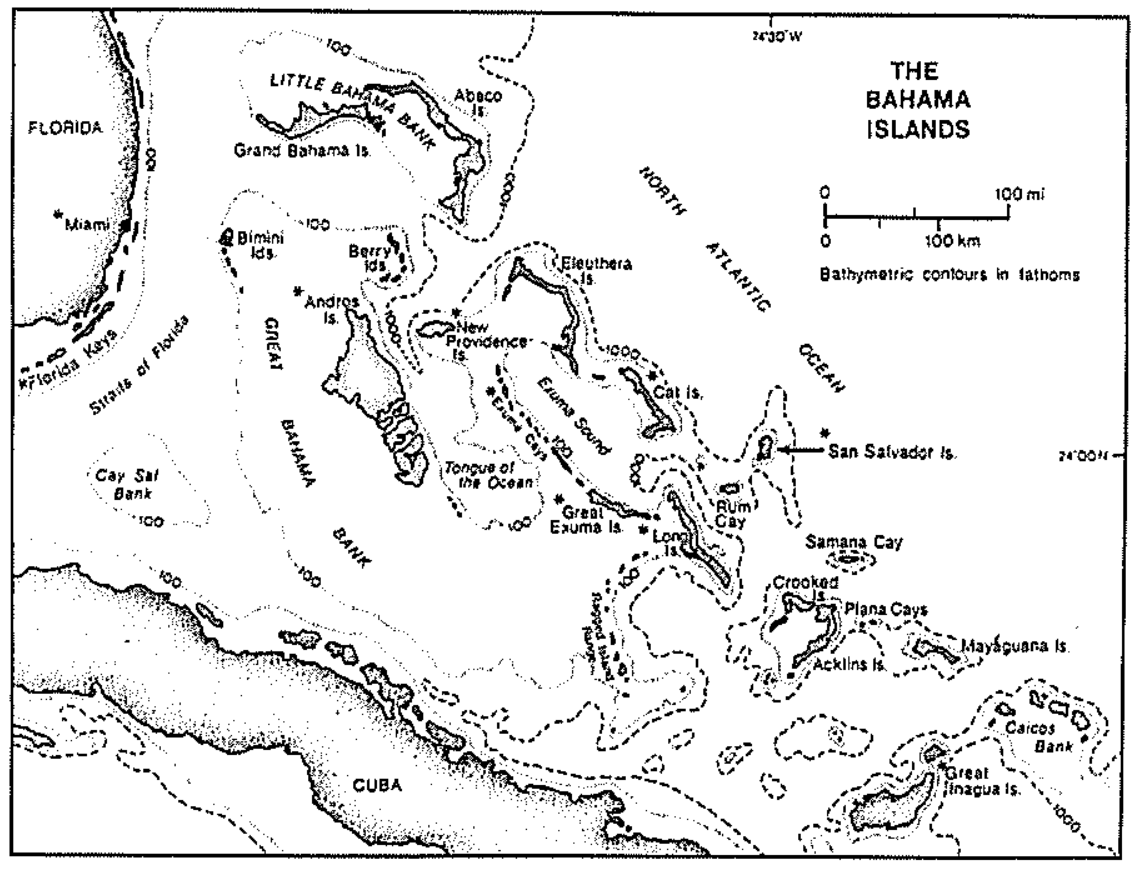

FIGURE 14.1 Index map to the principal islands of the Bahama Archipelago and southeastern Florida. Asterisks indicate locations specifically mentioned in this chapter. Modified from Curran and White (1995). 
involve carbonate substrates. There are important differences, both pros and cons, between the formation of trace fossils in carbonates versus siliciclastics, as summarized by Curran (1994, Table 3.1). In some respects, trace fossils can be better preserved in carbonate rocks than in siliciclastics, owing to the rapid lithification of carbonate sediments that commonly enhances preservation of tracks, trails, unlined burrows, and rhizomorphs. Most importantly, the ichnologic information gained from the study of carbonate environments should be integrated with, not divorced from, studies of siliciclastic settings. An example from this volume would be Chapter 1 by Goldring et al. that integrates ichnologic information from siliciclastic and carbonate settings to formulate a model for climatic control of trace fossil distribution.

\section{THE GEOLOGIC AND ICHNOLOGIC SETTING: BAHAMAS AND SOUTH FLORIDA}

The platforms and islands of the Bahama Archipelago and the region of south Florida are classic areas for the study of late Pleistocene and Holocene carbonate rocks and modern carbonate sediment-producing environments. Comprehensive reviews by Carew and Mylroie $(1995,1997)$ for the Bahamas, and Randazzo and Halley (1997) for south Florida and the Florida Keys present the general geology and stratigraphy for both areas.

The modern environments discussed herein range from shallow-subtidal, commonly reefal settings to beach and dune environments as they occur on sandy, windward or leeward island coasts. More protected muddy-sand environments that might occur marginal to a coastal embayment, such as a tidal flat-lagoon complex are also included. Figure 14.2 illustrates two hypothetical Bahamian islands and the spatial distribution of these coastal environments.

Late Pleistocene and Holocene calcarenite lithofacies that cap the Bahama Islands largely represent these environments, with the same being true for the south Florida region, although Holocene lithofacies are less well developed there. In the Bahamas, lithofacies commonly have limited aerial extent, but display sharp contacts in vertical section, form shallowing-upward sequences (Curran, 1994, Fig. 3.2), and record well the Quaternary history of glacio-eustatic sea-level change.

The definition of ichnocoenosis as given in the glossary of Bromley (1996) is followed herein; namely an ichnocoenosis represents an ecologically pure assemblage of traces or trace fossils derived from the activities of a single endobenthic community. In Bahamian-style settings, most trace fossil assemblages are true ichnocoenoses owing to the sharp lithofacies boundaries that characterize rock sequences in these areas. The exception is the occurrence of rhizomorphs formed by plant roots. Rhizomorphs are an integral, indeed sometimes dominant, part of the dunal ichnocoenosis, but they can also be formed by plant roots penetrating any preexisting lithofacies during any extended period of subaerial exposure with lowered sea level.

The side panel of Fig. 14.2 illustrates diagrammatically the five ichnocoenoses discussed in the following sections, with the ichnocoenoses keyed to their environments as might occur along the coasts of hypothetical Bahamian islands. The ichnocoenoses of the shallow-subtidal and intertidal environments are within the Skolithos ichnofacies as classically defined and most recently summarized by Bromley (1996), Pemberton et al. (2001), and Mcllroy (2004). In the seaward direction on a modern Bahamian platform shelf, one can observe an increase in trails, tracks, and other horizontal traces with increasing depth, suggesting transition to a Cruziana ichnofacies assemblage. This transition has not yet been documented in the rock record of the Bahamas or south Florida. The shelf-slope break at the edges of Bahamian platforms and off the Florida Keys is usually quite abrupt, and little is known about the deeper water ichnology of these areas.

The ichnocoenoses of the sandy beach and coastal dunes environments conform to the definition of the Psilonichnus ichnofacies as originally conceived by Frey and Pemberton (1987) and more recently defined by Pemberton et al. (2001) and Mcllroy (2004). Nesbitt and Campbell (2006) recently presented an in-depth discussion of this ichnofacies and environmental significance of the ichnogenus Psilonichnus. Their Fig. 1 illustrates well the environmental relationships between the Psilonichnus ichnofacies and adjacent ichnofacies in a marine coastal-estuarine setting and the possible distribution of Psilonichnus ichnospecies.

\section{ICHNOCOENOSES OF THE SKOLITHOS ICHNOFACIES}

Carbonate-sand substrates of tropical, shallowsubtidal environments are dominated by the burrowing activities of endobenthic thalassinidean shrimp, 


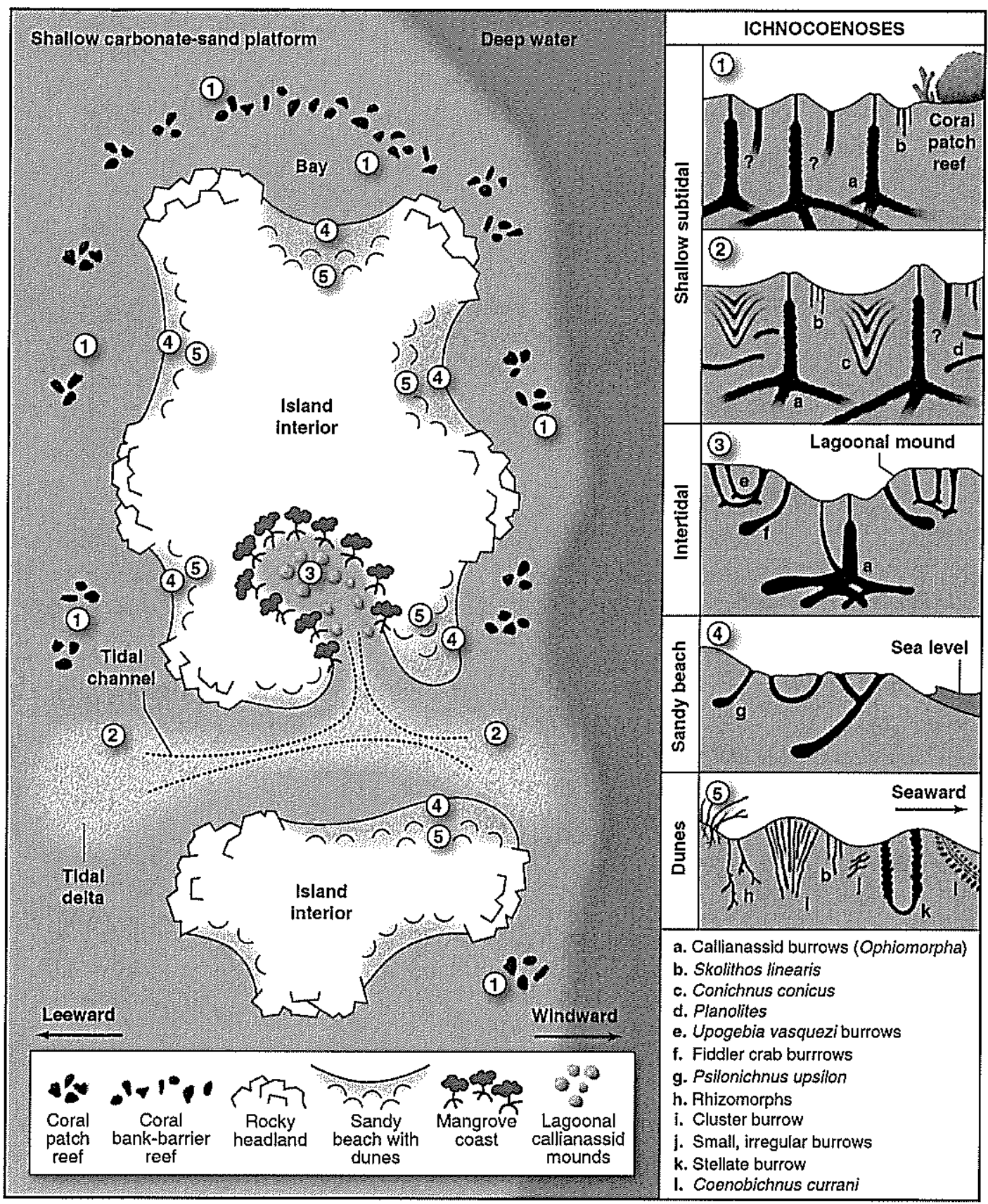

FIGURE 14.2 Hypothetical aerial view of two Bahamian islands and their coastal environments. The panel at right illustrates the ichnocoenoses discussed in this chapter; numbers key each ichnocoenosis to its environment of occurrence and letters indicate the traces present in each ichnocoenosis. Other modern tropical carbonate settings and their rock-record equivalents elsewhere in the world likely would be characterized by similar ichnocoenoses.

particularly callianassids, where 'they often occur in high densities and influence the whole sedimentology and geochemistry of the seabed' (Dworschak, 2004). Ichnologists and sedimentologists must be aware that there are many species distributed worldwide within the families Callianassidae and Upogebiidae (the latter discussed in the lagoonal ichnocoenosis section). In a recent survey of the diversity of extant 
thalassinideans, Dworschak (2000) recorded 155 species of callianassids and 139 species of upogebiids. Possibly of greater interest to ichnologists and sedimentologists is that most thalassinidean species are found in shallow-marine waters, and for callianassids and upogebiids, the great majority live in water depths of less than $20 \mathrm{~m}$, with by far the highest numbers of species found at tropical to subtropical latitudes (Dworschak, 2000).

With their widespread distribution in tropical, shallow-subtidal to intertidal carbonate environments, complex burrow systems, and prodigious bioturbation capabilities, callianassids are true allogenic ecosystem engineers in the sense of Jones et al. (1994). Articles by Berkenbusch and Rowden (2003) on Callianassa filholi in New Zealand and by Curran and Martin (2003) on Glypturus acanthochirus in the Bahamas and wider Caribbean document the activities of these callianassids as ecosystem engineers. Thus it comes as no surprise that callianassids dominate the ichnocoenoses of the Skolithos ichnofacies in the shallow-subtidal Quaternary calcarenites of the Bahamas and south Florida, as described below. This should also be expected to be the case in other geologically similar areas. Note that the numbers in parentheses for each ichnocoenosis section are keyed to the ichnocoenoses panel of Fig. 14.2 and the summary of Table 14.1 .

\section{Shallow Subtidal Ichnocoenosis (1)}

Surfaces of the modern tropical, shallow-subtidal, sandy-shelf environments of the Bahama Islands, Florida Keys, wider Caribbean region, and beyond commonly exhibit a mounded topography resulting from the bioturbation activity of callianassids (Fig. 14.3A,B). Sediment cones or 'volcanoes' are usually diminished in areas of strong wave and/or current energy and will be commonly obliterated during storms, only to return with fair weather, attesting to the prodigious bioturbation capabilities of tropical callianassids.

Some of the many effects of callianassids on the preservation of carbonate grains were documented by Tudhope and Scoffin (1984), but sedimentologists and ichnologists must keep in mind that these tropical-shelf callianassids remain poorly known with respect to species identifications, burrow morphology, and general ecology. As an example, two species of Neocallichirus were identified from the shallow-shelf area off the north coast of San Salvador Island (Curran, 1997), but details of the burrow morphologies are unknown (Fig. 14.3A,B).
The study of Dworschak and Ott (1993) on decapod burrows in the shallow-marine environments off Belize clearly indicated the ecologic and ichnologic complexities involved.

Ophiomorpha is the dominant ichnotaxon occurring in late Pleistocene shallow-subtidal calcarenites of the Bahamas and south Florida. In the Bahamas, Ophiomorpha burrow systems are commonly well preserved (Fig. 14.3C,D) and have been described in detail (Curran and White, 1991; Curran, 1994, and references cited therein). Ophiomorpha-bearing calcarenites commonly occur in association with fossil coral reefs and interfinger with coral rubblestones, as at the Cockburn Town reef on San Salvador and the Devil's Point reef on Great Inagua, where Ophiomorpha tunnels and mazes are surprisingly robust. Skolithos linearis is always present but secondary to Ophiomorpha, occurring in greatest densities in calcarenites formed in the shallowest marine parts of shallowing-upward sequences (Fig. 14.3E).

The late Pleistocene Miami Limestone (Oolite) of the Miami area and lower Florida Keys is a wellknown unit of shallow-subtidal origin that displays three distinct facies, bryozoan, bedded, and mottled, with the mottled facies characterized by the commonly abundant presence of trace fossils (Halley and Evans, 1983; Evans and Ginsberg, 1987). The dominant trace fossil of the mottled facies is Ophiomorpha. In this facies, post-depositional modification of the peloid-ooid sediments by callianassid tracemakers and subsequent diagenesis has produced a highly distinctive Ophiomorpha ichnofabric in many outcrops (Fig. 14.3F).

\section{Shallow Subtidal Ichnocoenosis with Conichnus conicus and Planolites (2)}

With the addition of Conichnus conicus and Planolites, this ichnocoenosis represents an extension of Ichnocoenosis 1. Its occurrence can be gradational or interfingering with Ichnocoenosis 1, as seems commonly the case within the Miami Limestone. In the Bahamas, where the lateral extent of outcrops is normally much more limited, such interfingering has not been observed but undoubtedly occurred in the original depositional settings. Additional subichnocoenoses might be established in the future for cases where $C$. conicus or Planolites becomes dominant, as for some beds of the Miami Limestone (Halley and Evans, 1983).

In late Pleistocene carbonate rocks, Conichnus conicus occurs most commonly in grainstones characterized by tabular and trough cross-bedding and 

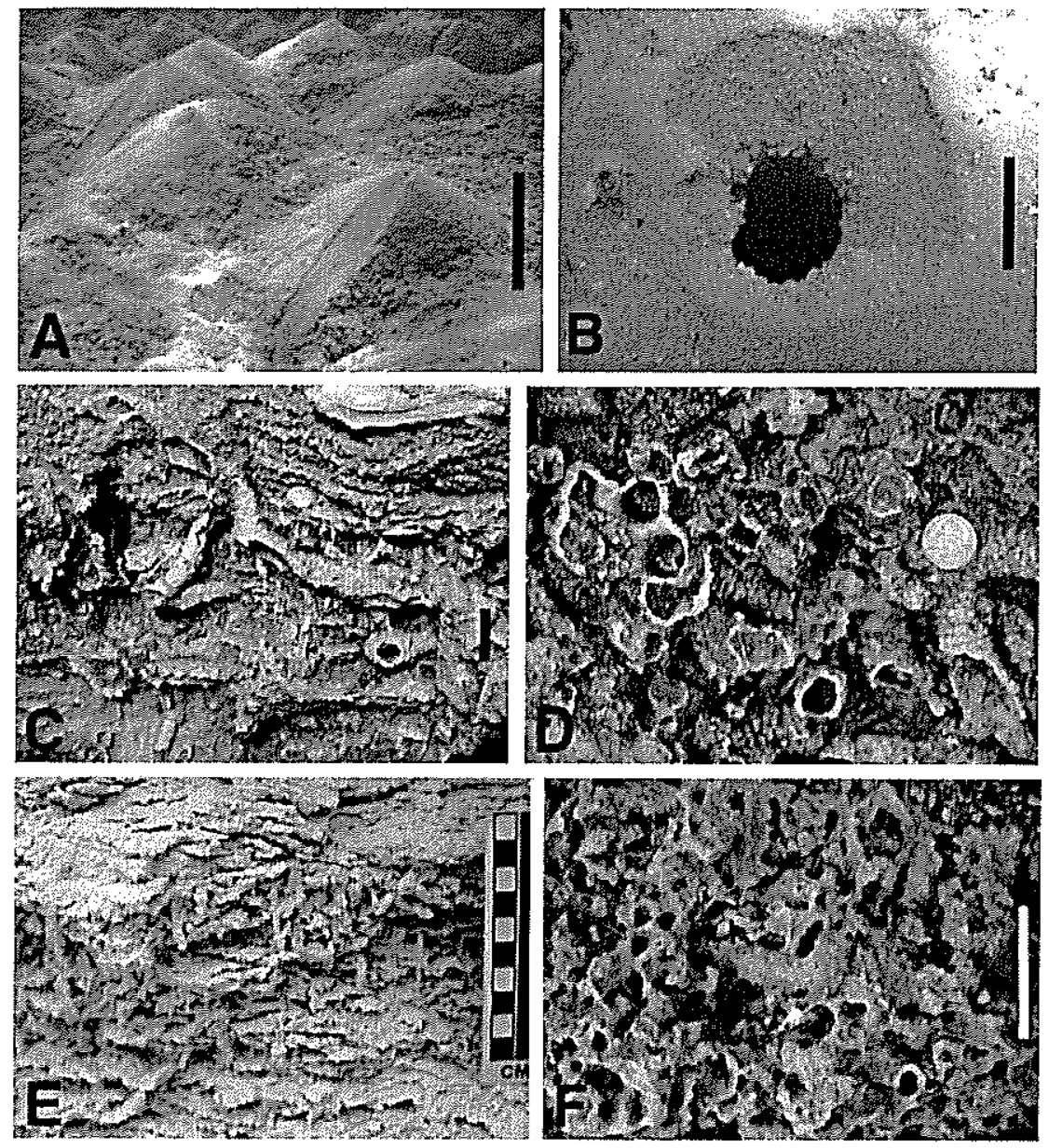

FIGURE 14.3 Ichnocoenosis 1-Shallow subtidal environment: (A) mounded shallow-shelf surface off San Salvador Island, Bahamas reflects the intense burrowing activity of deep-tier callianassid shrimp. Scale bar $=15 \mathrm{~cm}$. (B) Opening of callianassid burrow shaft in a shallow, funnel-shaped depression, same location as (A). Such openings occur commonly between sediment mounds or 'volcanoes.' Scale bar $=4 \mathrm{~cm}$. (C) Well-developed shafts and tunnels of Ophiomorpha in the Cockburn Town Member of the Grotto Beach Formation, late Pleistocene, Cockburn Town Fossil Reef on San Salvador. Calcarenite beds of this lithofacies interfinger with corals and coral rubblestone of the fossil reef. Scale bar $=4 \mathrm{~cm}$. (D) Horizontal surface with closely packed Ophiomorpha shafts and an open maze structure (left), same location as (C). Coin $=2.5 \mathrm{~cm}$ in diameter. (E) Dense occurrence of Skolithos linearis burrows, same location and lithofacies as $(C, D)$, in shallowing-upward sequence. $(F)$ Vertical surface reveals closely packed Ophiomorpha tunnels (maximum ichnofabric development), Miami Limestone, late Pleistocene, outcrop bounding the campus lake, University of Miami, Coral Gables, Florida. Pen $=15 \mathrm{~cm}$.

interpreted as representing relatively rapid sediment accumulation under shallow-subtidal, shoaling conditions influenced by nearshore and/or tidal currents. In the Bahamas, C. conicus specimens are common and well developed in exposures at Harry Cay on Little Exuma, just south of Great Exuma Island, and in the coastal exposures at Clifton Pier on New Providence Island (Curran and White, 1997). A minor occurrence is also present in the uppermost shallowing-upward beds at the north end of the Cockburn Town fossil reef on San Salvador. The uppermost shallowing-upward beds at Harry Cay contain abundant large $C$. conicus specimens in association with Ophiomorpha (commonly preserved as large tunnel and maze segments) and Planolites (Fig. 14.4A-D). A similar assemblage is present at Clifton Pier (Fig. 14.4E, F), although Ophiomorpha specimens are less robust here and Planolites is less abundant. 

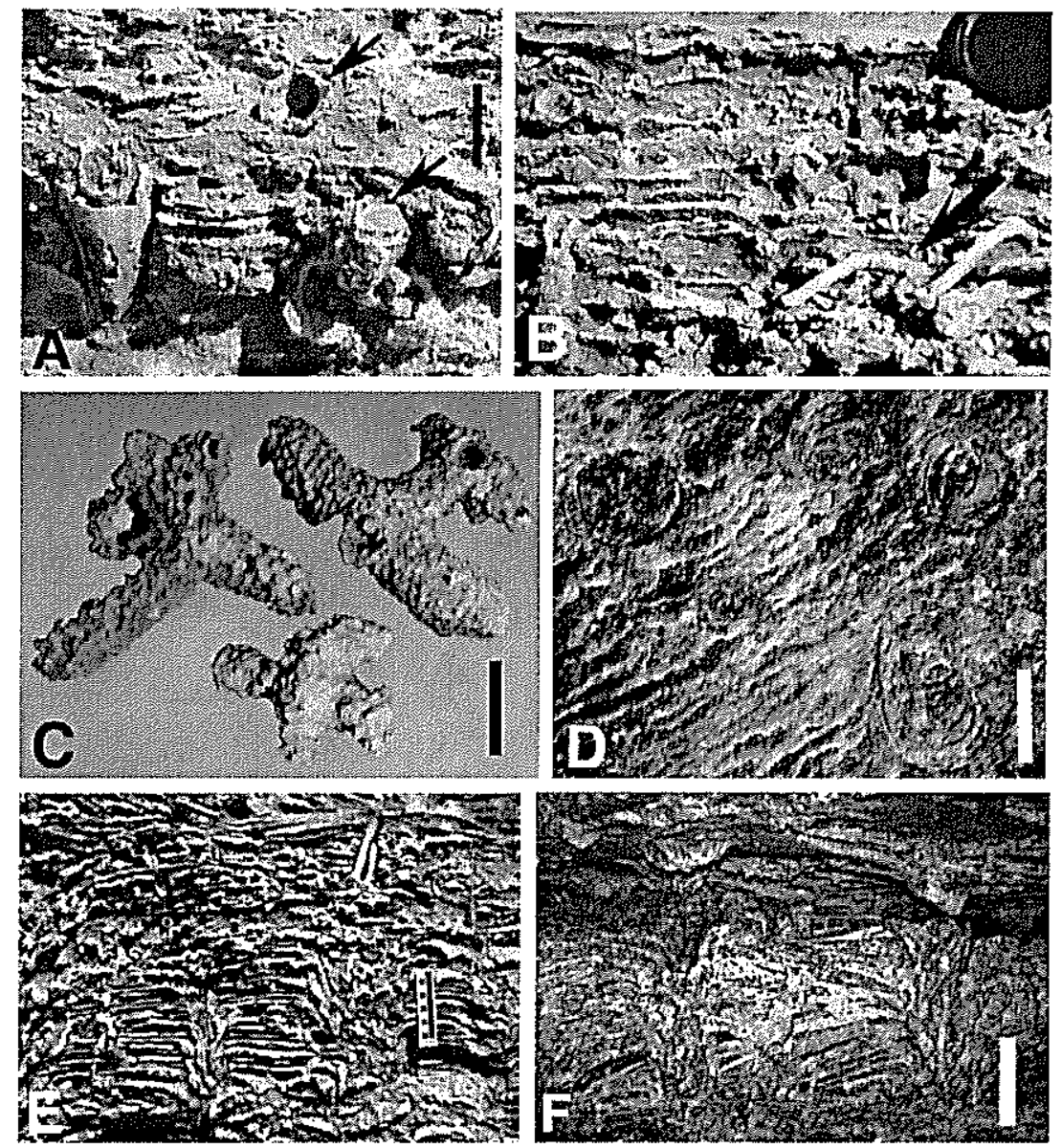

FIGURE 14.4 Ichnocoenosis 2-shallow subtidal environment: (A) Conichnus conicus, mediumsized specimen at left, and Ophiomorpha (arrows) in late Pleistocene cross-bedded, shallowsubtidal calcarenites exposed in a quarry wall, Harry Cay, Little Exuma Island, Bahamas. Ophiomorpha shaft at lower arrow cuts into a large $C$. conicus specimen. Scale bar $=6 \mathrm{~cm}$. (B) Same location and outcrop as (A) with Ophiomorpha shafts and tunnels and Planolites specimens (arrow). Caliche layer at top of outcrop marks the Pleistocene-Holocene disconformity. Lens cap $=5.5 \mathrm{~cm}$ diameter. (C) Well-lithified and robust tunnel and maze specimens of Ophiomorpha weathered out from horizontal exposures of the late Pleistocene cross-bedded calcarenites at Harry Cay. Scale bar $=6 \mathrm{~cm}$. (D) Horizontal surface, same as (C), with closely spaced cross sections of large C. conicus specimens; an Ophiomorpha shaft cuts into the C. conicus specimen at lower right. Scale bar $=6 \mathrm{~cm}$. (E) Ophiomorphn-C. conicus ichnofabric in late Pleistocene cross-bedded calcarenites, coastal outcrop at Clifton Pier, New Providence Island, Bahamas. Scale $=10 \mathrm{~cm}$. (F) Walls of a sea cave, same location as (E), reveal large $C$. conicus specimens; knobs at top are extensions of the $C$. conicus specimens into the cave roof. Scale bar $=12 \mathrm{~cm}$.

Elsewhere, Conichnus conicus is common in many outcrops of the Miami Limestone in the Miami, Florida area (t)alley and Evans, 1983), particularly in beds that are tabular cross-bedded. Some beds of the Miami Limestone are dominated by Planolites, interpreted by Halley and Evans as indicating more stabilized areas of the oolite shoal-bar complex. In the late Pleistocene Ironshore Formation of Grand
Cayman Island, Pemberton and Jones (1988) recorded a similar assemblage of trace fossils, with $C$. conicus best developed in cross-bedded oolitic sands in a shallowing-upward sequence that was interpreted by Jones and Pemberton (1989) to have formed in a backreef lagoonal setting, likely to be similar to parts of the Miami Limestone depositional system and those of the Bahamas examples. 
The origin of Conicus conicus is generally attributed to the escape-burrowing activities of sea anemones. This is based on the studies of Shinn (1968) who made field observations of the sea anemone Phyllactis conguilegia burrowing in oolitic sands of the Bahamas Banks and then collected specimens and conducted an aquarium experiment to record the burrowing activity of this anemone. With repeated applications of layers of sediment, $P$. conguilegia produced a biogenic structure (Shinn, 1968, p. 112, Figs. 1-4) that is closely comparable to C. conicus specimens from both the Miami Limestone and the Clifton Pier locality. However, caution is warranted based on a recent study by Buck and Goldring (2003) titled 'Conical structures, trace fossils or not?' Table 3 and summary Fig. 16 of Buck and Goldring give diagnostic criteria for making interpretations of conical sedimentary structures. Interpretation as sea anemone escape burrows remains viable for $C$. conicus in Quaternary tropical grainstones, but the usual ichnologic guidelines of consistency of form, size, and occurrence should be followed. In addition, further field observations of escape-burrowing activity in the appropriate modern depositional environments are needed for better understanding of the significance of this trace fossil.

\section{Lagoonal Intertidal Ichnocoenosis (3)}

In the Bahamas, semi-enclosed, tidally influenced, slightly hypersaline lagoonal areas, sometimes referred to as 'creeks,' are common coastal features. An example is Pigeon Creek, at the southeast corner of San Salvador Island, where the intertidal margins of the lagoon are bordered by a zone of fringing mangroves that commonly gives way lagoonward to extensive carbonate muddy-sand flats. The ichnology of these flats and discussion of trace fossil analogs and rock record implications were recently reviewed by Curran and Martin (2003), so only the major points will be covered here. It should be noted that the Pigeon Creek tidal flats are much smaller in area and consist of coarser sediments than the extensive, muddominated nearshore zone and tidal flats on the west side of Andros Island described in the Hardie (1977) volume. From this area, Garrett (1977) described several communities (nearshore, pond, and levee) that could be regarded as a separate ichnocoenosis or ichnocoenoses.

The tidal flats at Pigeon Creek and other, similar areas display a distinctive topography of mounds and craters formed by the callianassid shrimp Glypturus acanthochirus (Fig. 14.5A, B). As discussed earlier, this deep-tier burrower is a true ecosystem engineer, owing to its profound modification of the intertidal and shallow-subtidal areas that it inhabits. Described in detail by Dworschak and Ott (1993) and Curran and Martin (2003), G. acanthochirus burrows are large and well lined, with smooth interior and pelleted exterior surfaces, and complex, with a distinctive, downwardspiraling morphology. Previous studies by Shinn (1968) and by Tedesco and Wanless (1991) from Florida, the Bahamas, and the Caicos Platform described casts of burrows with similar morphologies that were generically attributed to 'Callianassa.' Based on the more recent information, the burrows from these study areas probably were also formed by G. acanthochirus and indicate a distribution for this species throughout the wider Caribbean. Also of note is that Farrow (1971) described casts of large, spiraling callianassid-burrow systems from carbonate substrates on Aldabra Atoll in the Seychelles. Given the geographic separation, it is highly unlikely that those burrows were formed by G. acanthochirus, but this does give strong indication that a downwardspiraling morphology is widespread for callianassids in tropical, intertidal and shallow-subtidal, carbonate substrates.

Surfaces of the coalesced mounds formed by Glypturus acanthochirus become a stable substrate for colonization by other burrowers, as described in detail by Curran and Martin (2003). Most distinctive are the burrows of Upogebia vasquezi (Fig. 14.5C,D). These complex but much smaller burrows penetrate $10-15 \mathrm{~cm}$ into the surfaces of the mounds and are thickly lined, with smooth interior and coarsely knobby exterior surfaces. The burrow resin casts reveal a double-U form, with the U-shapes commonly criss-crossing within the thick walls of the burrow system. These U-shapes have no apparent interior interconnection, but each burrow system contains a male and a female shrimp. U. vasquezi burrow systems are common on the mounds at Pigeon Creek, averaging about 5 burrows per $\mathrm{m}^{2}$ (Curran and Martin, 2003).

Also present on the mound surfaces are the openings of numerous burrows of fiddler crabs. The larger openings, commonly surrounded by scratch marks and numerous excavations and feeding pellets, are formed by adult Uca major, with the smaller openings created by juvenile $U$. major specimens and/or other unidentified Uca species. Large $U$. major burrows have openings of $3-4 \mathrm{~cm}$, are unlined, with interior diameters of $2-5 \mathrm{~cm}$, and extend obliquely into the mounds for distances of up to $50 \mathrm{~cm}$, ending with a bulbous turnaround where the 

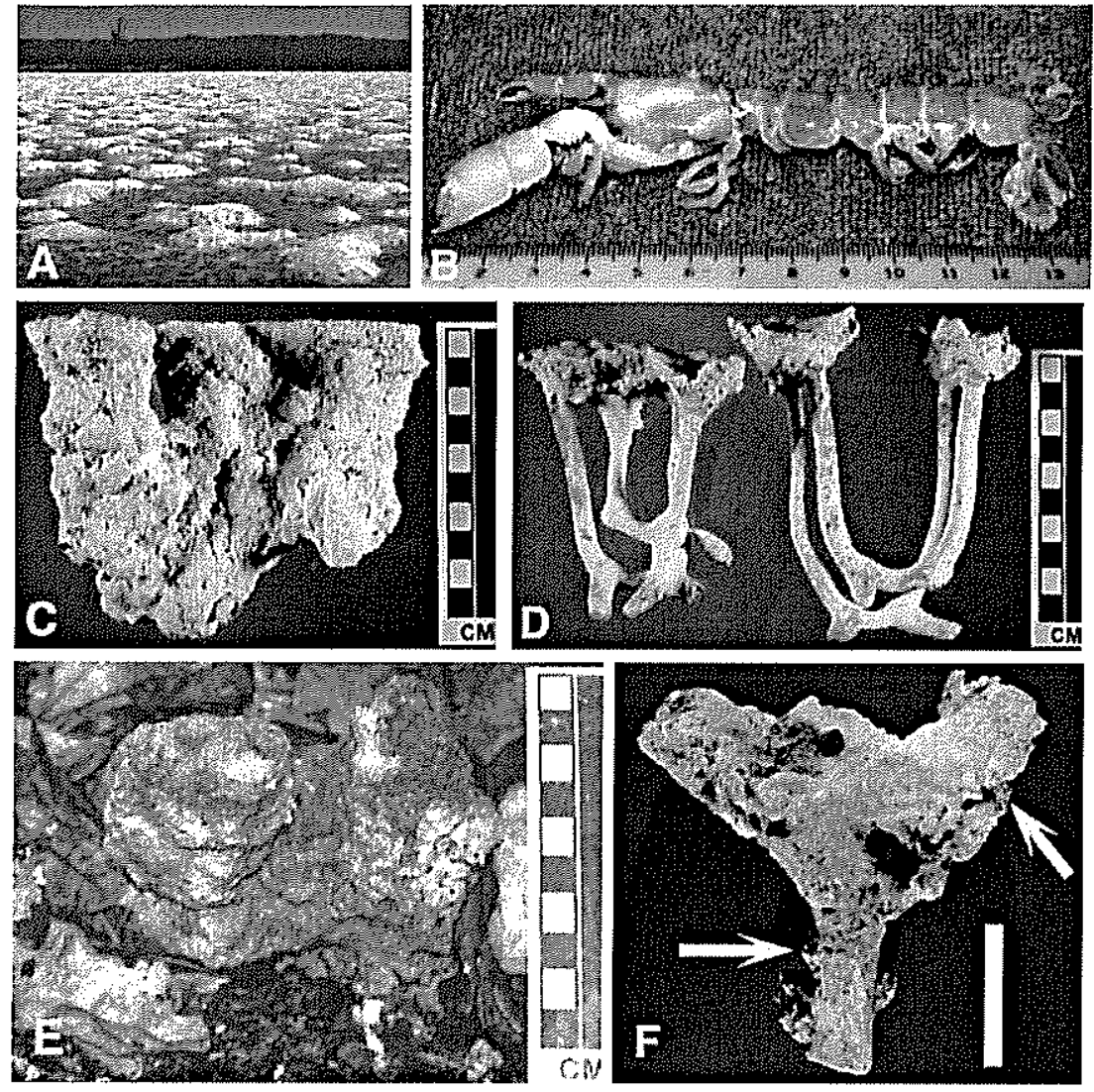

FIGURE 14.5 Ichnocoenosis 3-lagoonal intertidal environment: (A) view across tidal flat at Pigeon Creek on San Salvador Island illustrating the mounded topography generated by the callianassid Glypturus acanthochirus. (B) Mature specimen of G. acanthochirus from Pigeon Creek. (C) Exterior of a thickly lined Upogebia vasquezi burrow extracted from a can core taken from surface of a mound as shown in (A). Note knobby character of the outer burrow wall. (D) Resin casts of $U$. vasquezi burrows from Pigeon Creek showing the distinctive double-U form and short tunnels at bases of the Us. (E) In situ fossil $U$. vasquezi burrow in a lagoonal facies of the Cockburn Town Member of the Grotto Beach Formation, late Pleistocene, near Osprey Lake, San Salvador. (F) Composite trace fossil specimen collected in situ from same rock unit and location as $(E)$. Arrow at left marks the lithified fill of a callianassid burrow shaft, presumably formed by G. acanthochirus; arrow at right points to the outer surface of a near-complete $U$. vasquezi burrow. Scale bar $=6 \mathrm{~cm}$.

crab is commonly found (Curran and Martin, 2003, Fig. 8; not depicted herein).

Protected lagoonal-intertidal facies have not been widely recognized and described from the late Pleistocene rocks of the Bahamas. This is somewhat surprising given the likely widespread occurrence of this facies on Bahamian islands, but island-interior areas where such a facies might be present typically are low-lying, heavily vegetated, and thus poorly exposed and hard to access. In a late Pleistocene facies of the Grotto Beach Formation on San Salvador, Curran and Martin (2003) described trace fossils identified as Upogebia vasquezi burrows in association with the tops of presumed Glypturus acanthochirus burrow shafts (Fig. 14.5E, F). No formal ichnotaxa have been established for these burrows pending collection of better-preserved material, but this indicates that this facies can be recognized in the future with the occurrence of distinctive trace fossils as an aid. Furthermore, the presence of fossil $U$. vasquezi burrows should be useful for pinpointing past sea-level positions. To my knowledge, no fossil fiddler crab burrows have been found in late Pleistocene carbonate rocks. If fossil fiddler crab burrows are discovered in the future, they would seem to be assignable to the ichnogenus Psilonichnus, thus 
extending the environmental range of this ichnogenus to the tropical-intertidal zone, following the view of Nesbitt and Campbell (2006) for Psilonichnus in shallow-subtidal to intertidal siliciclastic environments.

\section{ICHNOCOENOSES OF THE PSILONICHNUS ICHNOFACIES}

The initial description by Frey and Pemberton (1987) of the Psilonichnus ichnofacies, originally designated the Psilonichnus Ichnocoenose, was largely based on the ichnologic characteristics of the modern siliciclastic shorelines of the Georgia Sea Isles. Specifically, the Psilonichnus Ichnocoenose was established to correspond ichnologically to the sedimentologic zones of the beach backshore and dunes, or washover fans and supratidal flats .... based upon typical occurrences of the trace fossil Psilonichnus upsilon' (Frey and Pemberton, 1987).

In the Bahamas, carbonate sand beaches tend to be steep and narrow and are normally backed by heavily vegetated dunes. Here the burrowing activity of Ocypode quadrata, the tracemaker of Psilonichnus upsilon, is largely restricted to the beach backshore zone. O. quadrata does not normally inhabit dunes, likely owing to vegetation cover which impedes its mobility, and also possibly because of the abundant presence of the common land crab, Gecarcinus lateralis, within dunal areas. This differs from the distribution of $O$. quadrata in coastal siliciclastic settings, where ghost crabs commonly range well back into the dunes (Curran and White, 1991; Curran 1994).

Following the original concept of the Psilonichnus ichnofacies (Frey and Pemberton, 1987; and later researchers), the modern coastal dunes and Holocene and Pleistocene carbonate eolianites of the Bahamas fall within this ichnofacies, as presented below. All islands of the Bahamas Archipelago are capped by carbonate eolianites to at least some degree, with this commonly being the dominant Holocene/Pleistocene lithofacies. It follows that the dunal ichnocoenosis of the Psilonichnus ichnofacies should be well represented in carbonate eolianites throughout the Bahamas, and this is likely the case for similar carbonate eolianites globally.

\section{Sandy Beach Ichnocoenosis (4)}

This ichnocoenosis is characteristic of the sandy carbonate beaches of the Bahamas and elsewhere in the wider Caribbean and beyond, as well as equivalent Holocene calcarenites in the Bahamas and Pleistocene calcarenites of Bermuda. The ichnocoenosis is dominated by the distinctive modern burrows of ocypodid crabs (i.e., ghost crabs) and the trace fossil Psilonichnus upsilon. In the Bahamas, the analog relationship between the Ocypode quadrata, its modern burrows, and the trace fossil $P$. upsilon has been well established (Frey et al., 1984; Curran and White, 1991; Curran, 1994). Typical morphologies for P. upsilon are exhibited in Holocene beach-backshore beds in the Bahamas (Fig. 14.6A-D) and in an analogous facies of middle Pleistocene age on Bermuda (Fig. 14.6E-G). A recent article by De (2005, Fig. 2) illustrated an even greater range of morphologies for burrows constructed by several species of Ocypode in modern siliciclastic beaches of the Ganges Delta Complex of India.

In the Bahamas, I have found Psilonichnus upsilon in every Holocene beach-backshore sequence examined, including on San Salvador, Cat, Lee Stocking, Long, and North Andros islands. The backshore zone is seemingly not as well represented in the Pleistocene beach to dune sequences of the Bahamas, and $P$. upsilon has not yet been reported from these rocks. However, $P$. upsilon is strikingly common in a beach-dune coastal exposure of the middle Pleistocene Belmont Formation on Bermuda (Fig. 14.6E-G; Curran, 1994, Fig. 3.11). In this example, the occurrence of $P$. upsilon has real value as a stratigraphic sea-level position indicator, with potential for use in other similar tropical-carbonate areas around the world, as briefly discussed by Curran (1994).

\section{Dunal Ichnocoenosis (5)}

The occurrence of trace fossils in Bahamian carbonate eolianites is well established, with the ichnofossils described in detail by Curran and White (2001). The paradox is that this is the most diverse ichnocoenosis within the two ichnofacies discussed in this review, whereas in earlier times, dunal beds were thought to have a minor trace fossil component at best. A useful summary of the architecture of Bahamian coastal carbonate eolianites was given by Carew and Mylroie (2001), and the mesoscale physical sedimentary structures were described by White and Curran (1988), along with some of the trace fossils.

As noted earlier, the presence of rhizomorphs is a ubiquitous aspect of these eolianites. Concentrated occurrences of rhizomorphs can completely obscure original bedding structures and textures and generate maximum ichnofabric development in eolianites, 

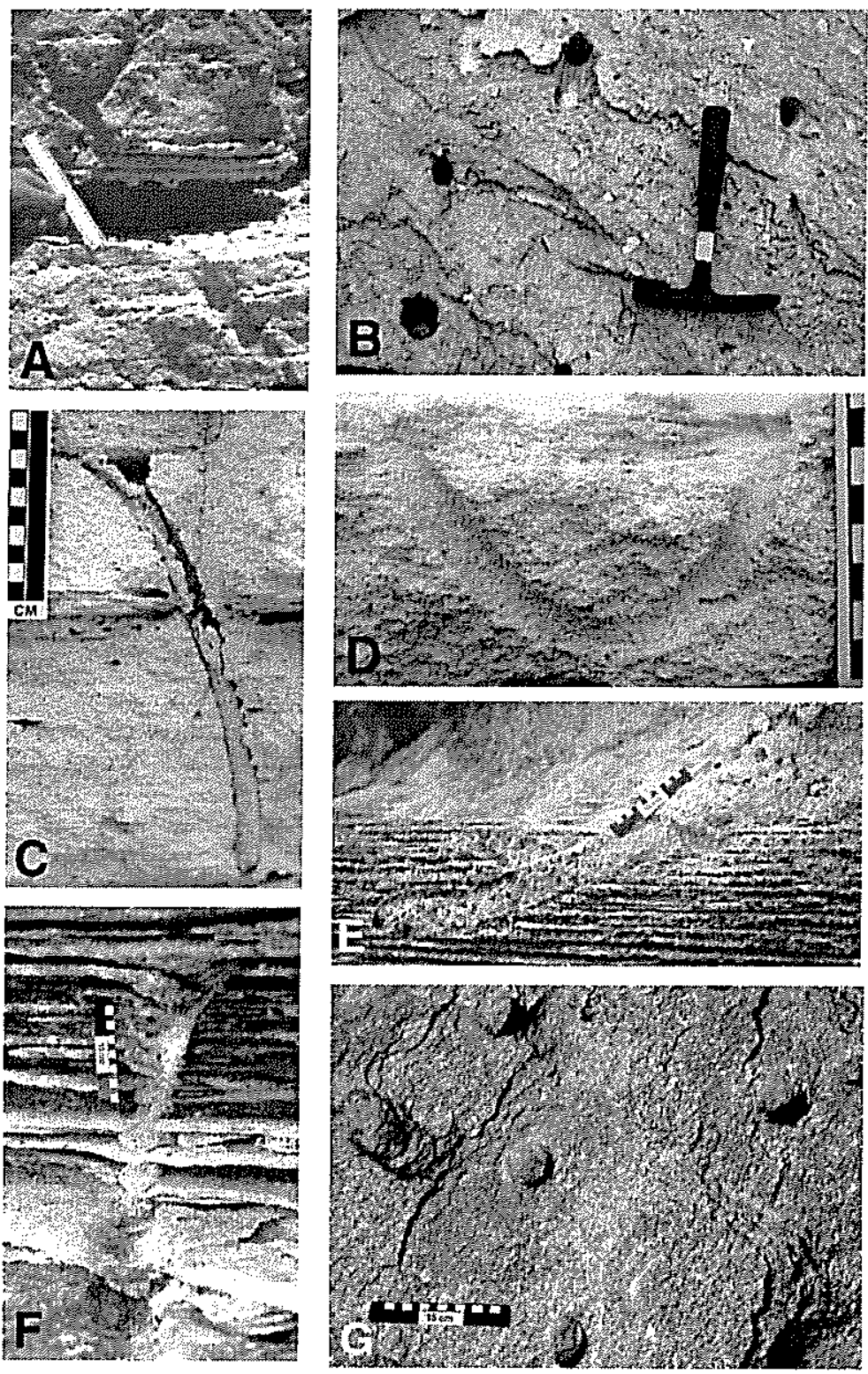

FIGURE 14.6 Ichnocoenosis 4-sandy beach environment: all photos illustrate specimens of Psilonichnus upsilon, the trace fossil formed by ghost crabs that characterizes this ichnocoenosis and is best developed in the backshore zone. (A) A classic Y-shaped specimen of $P$. upsilon in the Hanna Bay Member of the Rice Bay Formation, Holocene, Hanna Bay cliffs on San Salvador. Scale $=15 \mathrm{~cm}$. This is a different specimen from the holotype of Frey et al. (1984), also from this locality. (B) Horizontal surface on backshore calcarenite beds revealing the circular cross sections of P. upsilon shafts; Lee Stocking Island of the Exuma Cays, Bahamas, in Holocene beds equivalent to Hanna Bay Member on San Salvador. Hammer length $=28 \mathrm{~cm}$. (C) View of full shaft of $P$. upsilon, same location as (B). (D) Small, U-shaped specimen of $P$. upsilon, likely made by a juvenile ghost crab, same location as (B). Scale in centimeters. (E) Large P. tupsilon specimen in backshore calcarenite beds of the Belmont Formation, middle Pleistocene, Doe Bay, Bermuda. Scale $=15 \mathrm{~cm}$. (F) Another well-developed $P$. upsilon shaft, same location and scale as (E). (G) Bedding-plane view of the Belmont Formation backshore beds, similar to (B), with circular, burrow-fill cross sections of $P$. upsilon shafts and indicating the potential of $P$. upsilon to generate an ichnofabric, same location and scale as $(\mathrm{E})$. 

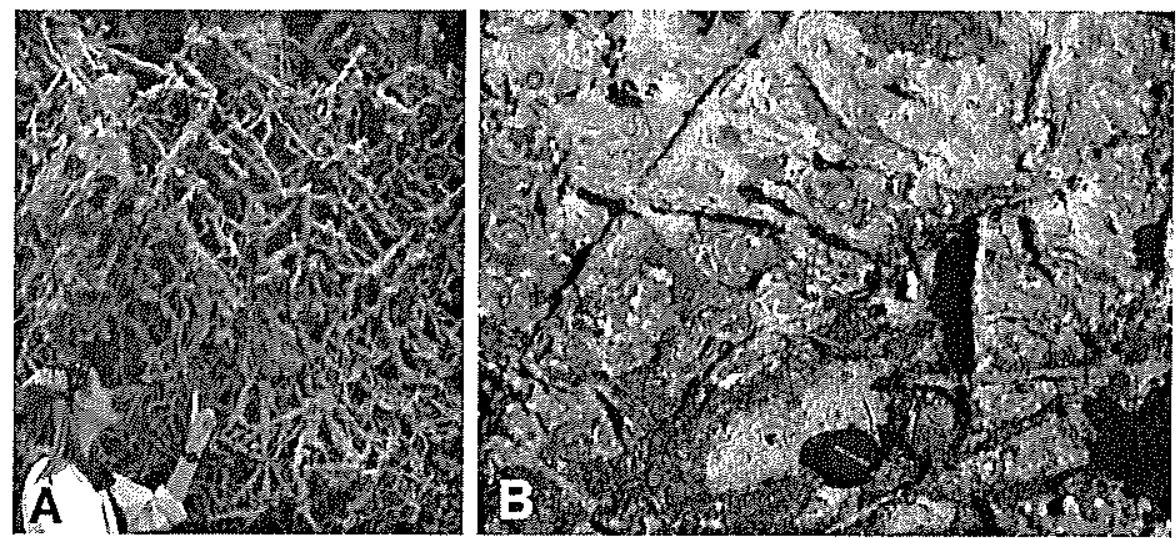

FIGURE 14.7 Ichnocoenosis 5-dunal environment: the development of rhizomorphs can significantly modify the original texture of carbonate eolianites. (A) Dense occurrence of rhizomorphs in coastal outcrop of late Pleistocene eolianites of the Cockburn Town Member of the Grotto Beach Formation at Crab Cay on San Salvador. (B) Horizontal surface of thin caliche layer intercalated with Holocene eolianites of the North Point Member of the Rice Bay Formation on San Salvador; rhizomorphs likely formed by railroad vine and/or bay geranium. Lens cap $=5.5 \mathrm{~cm}$ in diameter.

particularly in late Pleistocene eolianites formed during sea regression (Fig. 14.7A). Thin caliche (micritic) crusts with well-developed rhizomorphs parallel to bedding are particularly common in the Holocene eolianite sequences (Fig. 14.7B) and represent short breaks in the build up of the dunal sands (White and Curran, 1988, Figs. 10, 11).

Arthropods of various types are the likely tracemakers for all five of the animal trace fossils previously described from Bahamian eolianites. Skolithos linearis burrows (see Curran and White, 2001, Figs. 5C,6) are always present but scattered and never dominant. The largest and most striking trace fossils in these eolianites are the cluster burrows (Fig. 14.8A, B), attributed to the brooding and hatching activities of sphecid (digger) wasps, and the stellate burrows (Fig. $14.8 \mathrm{C}, \mathrm{D}$ ), resulting from the nesting activities of halictid (sweat) bees. Both forms are common and well preserved in the Holocene beds of the Hanna Bay Member of the Rice Bay Formation, and cluster burrows are common in the North Point Member of this formation on San Salvador. Both also occur in sufficient abundance to create an ichnofabric (Fig. 14.8B, D), at least locally. Cluster burrows have been reported from Holocene eolianites on Lee Stocking Island in the Exuma Cays and from late Pleistocene eolianites exposed in a submarine cave on Norman's Pond Cay, also in the Exumas (Curran and White, 2001). More recently, I found both cluster and stellate burrows in Holocene eolianites on Cat, North Andros, and Long islands, Bahamas, indicating that their occurrence is likely to be widespread and to be expected given the requisite eolian environment. Both forms have not been named formally pending further research, but the ichnotaxonomic analysis of Genise (2000) suggests that the stellate burrows likely can be assigned to the new ichnogenus Cellicalichnus.

The small, irregular burrows (Fig. 14.8E), attributed to the burrowing activity of insects or insect larvae, can be abundant in Holocene Bahamian eolianites and can locally create a distinctive ichnofabric (Fig. 14.8E). In addition to their occurrence on San Salvador, these burrows have been reported from Holocene eolianites on Lee Stocking Island (Curran and White, 2001). They also occur in Holocene eolianites on Long Island, suggesting a potentially wide range of occurrence. Finally, the most recent addition to the dunal ichnocoenosis is Coenobichnus currani, a trackway attributed to a land hermit crab as described by Walker et al. (2003) from the Holocene North Point Member eolianites on San Salvador (Fig. 14.8G). Although only one fossil trackway is presently known from this locality, trackways of several types can be common on modern dune surfaces in the Bahamas (Fig. 14.8H), indicating real potential for the discovery of more fossil trackways and expansion of ichnotaxa in the dunal ichnocoenosis in the future.

The dunal ichnocoenosis is notable in several respects, as reviewed by Curran and White (2001), with the take-home message for ichnologists and sedimentologists being that a suite of animalgenerated trace fossils is to be expected in carbonate 

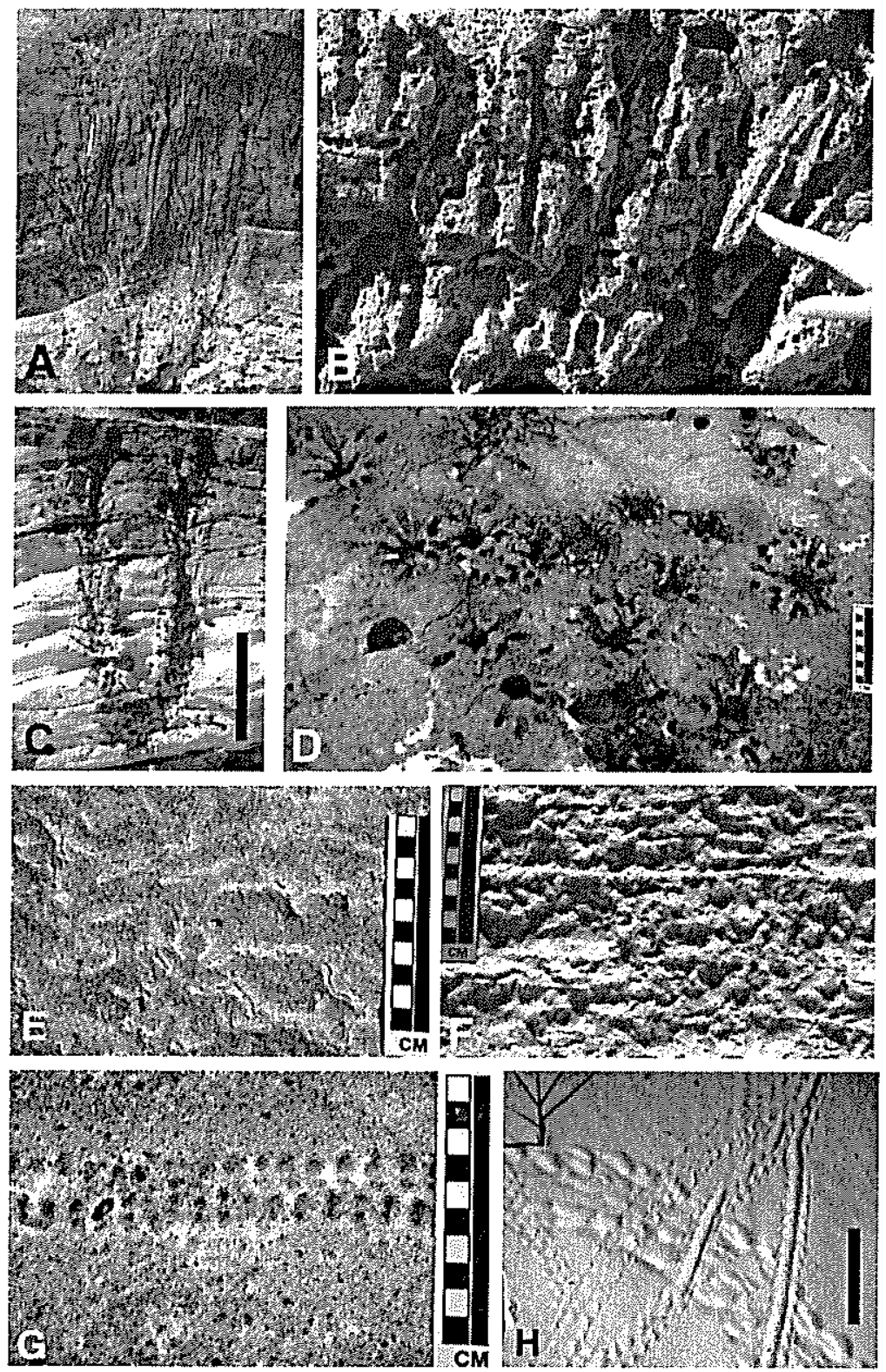

FIGURE 14.8 Ichnocoenosis 5-dunal environment: (A) vertical section of a large cluster burrow in coastal eolianite outcrop, North Point Member of the Rice Bay Formation, Holocene, North Point on San Salvador. Pen $=15 \mathrm{~cm}$. (B) Close-up of cluster burrow shafts indicating the capability of this burrow to impart an ichnofabric. Same location as (A); finger for scale. (C) Vertical section of a large and complete stellate burrow, Hanna Bay Member of the Rice Bay Formation, Hanna Bay cliffs on San Salvador. Scale bar $=14 \mathrm{~cm}$. (D) Eolianite bedding plane surface revealing the closely spaced occurrence of stellate burrow shafts and their potential to generate an ichnofabric. Same location as $(C) ;$ scale $=10 \mathrm{~cm}$. (E) Typical small, irregular burrows on a bedding plane in Holocene eolianites equivalent to the Hanna Bay Member, at Coral Gardens cliffs on Long Island, Bahamas. (F) Vertical view of ichnofabric generated by the small, irregular burrows in Holocene eolianite on Lee Stocking Island, Bahamas. (G) Section of the holotype specimen of Coenobichnus currani, a land hermit crab trackway; eolianite bedding plane, same location as (A). (H) Crisscrossing crab trackways in the sands of a modern dune, Coast Guard beach and dunes, adjacent to North Point on San Salvador. Scale bar $=6 \mathrm{~cm}$. 
eolianites, along with trace fossils of plant origin (rhizomorphs of varying types and orientations). Furthermore, dunal environment tracemakers are capable of generating ichnofabrics, so those working with more ancient carbonate rocks, particularly core samples, should consider a possible eolian interpretation when trace fossils and/or ichnofabrics similar to those discussed here are encountered.

\section{CONCLUSIONS}

Table 14.1 summarizes the ichnofacies, ichnocoenoses, ichnotaxa, and ichnofabrics of the modern, Holocene, and Pleistocene coastal carbonate depositional environments and limestones of the Bahamas and south Florida discussed in this chapter. Five ichnocoenoses, divided between the Skolithos and

TABLE 14.1 Summary of the Characteristics of the Ichnofacies and Ichnocoenoses Discussed and Illustrated in this Chapter, with an Evaluation of the Ichnofabric-Generating Potential of Each Ichnocoenosis

\begin{tabular}{|c|c|c|c|}
\hline Ichnofacies/Ichnocoenoses ${ }^{1}$ & Ichnotaxa ${ }^{2}$ & $\begin{array}{c}\text { Probable Tracemaker } \\
\text { Organisms } \\
\end{array}$ & $\begin{array}{c}\text { Ichnofabric Generation } \\
\text { Potential }^{3} \\
\end{array}$ \\
\hline \multicolumn{4}{|l|}{ Skolithos: } \\
\hline $\begin{array}{l}1 \text { Shallow subtidal, } \\
\text { open shelf, commonly } \\
\text { adjacent to coral reefs }\end{array}$ & $\begin{array}{c}\text { Ophiomorpha } \\
\text { Skolithos linearis }\end{array}$ & $\begin{array}{l}\text { Callianassid shrimp } \\
\text { Tube-dwelling polychaetes }\end{array}$ & High (3-5) \\
\hline $\begin{array}{l}2 \text { Shallow subtidal, } \\
\text { shoaling tidal delta- } \\
\text { channel settings }\end{array}$ & $\begin{array}{l}\text { As above, plus: } \\
\text { Conichnus conicus } \\
\text { Planolites }\end{array}$ & $\begin{array}{l}\text { Burrowing sea anemones } \\
\text { Balanoglossid worms }\end{array}$ & High (3-4) \\
\hline $\begin{array}{l}3 \text { Intertidal flats of } \\
\text { lagoon margins }\end{array}$ & $\begin{array}{l}\text { None presently } \\
\text { named }\end{array}$ & $\begin{array}{l}\text { Callianassid shrimp } \\
\text { (Glypturus acanthochirus) } \\
\text { Upogebiid shrimp } \\
\text { (Upogebia vasquezi) } \\
\text { Fiddler crabs } \\
\text { (Uca major) }\end{array}$ & High (3-5) \\
\hline \multicolumn{4}{|l|}{ Psilonichnus: } \\
\hline $\begin{array}{l}4 \text { Sandy beach, } \\
\text { ranging from high } \\
\text { foreshore into } \\
\text { primary } \\
\text { dunes; best } \\
\text { developed in } \\
\text { backshore zone }\end{array}$ & Psilonichnus upsilon & $\begin{array}{c}\text { Ghost crabs } \\
\text { (Ocypode guadrata) }\end{array}$ & Low to Moderate (1-3) \\
\hline \multirow[t]{6}{*}{5 Dunes } & $\begin{array}{l}\text { Coenobichmus currani } \\
\text { Skolithos linearis }\end{array}$ & $\begin{array}{l}\text { Land hermit crabs } \\
\text { Tube-dwelling insects }\end{array}$ & $\begin{array}{l}\text { Low to Moderate (1-3), } \\
\text { locally can be high } \\
\text { (4-5), particularly } \\
\text { from rhizomorphs }\end{array}$ \\
\hline & Cluster burrows & $\begin{array}{l}\text { Burrowing (digger) wasps, } \\
\text { Family Sphecidae }\end{array}$ & \\
\hline & $\begin{array}{l}\text { Small, irregular } \\
\text { burrows }\end{array}$ & Insects or insect larvae & \\
\hline & Stellate burrows & $\begin{array}{l}\text { Burrowing bees, } \\
\text { Family Halictidae }\end{array}$ & \\
\hline & Rhizomorphs-vertical & Plant roots & \\
\hline & Rhizomorphs-horizontal & $\begin{array}{c}\text { Plant stems and branches, } \\
\text { railroad vine (Ipomoen pes-caprae) } \\
\text { and bay geranium } \\
\text { (Ambrosin hispida) }\end{array}$ & \\
\hline
\end{tabular}

${ }^{1}$ Ichnocoenoses numbered following the panel diagrams of Fig. 14.2. ${ }^{2}$ Some informal names listed here, as used in previously published literature. ${ }^{3}$ Numbers from the ichnofabric index scale of Droser and Bottjer as in Mcllroy (2004, Fig. 4). 
Psilonichmus ichnofacies and representing environments ranging from the shallow-subtidal through dunal zones, are presently recognized, with expansion of this model likely with future investigations. The subtidal to intertidal ichnocoenoses of the Skolithos ichnofacies are dominated by the tracemaking activities and trace fossils of callianassid shrimp, which can create distinctive and maximum ichnofabrics, as commonly is the case in the subtidal calcarenites of the Miami Limestone. In the Bahamas, subtidal beds dominated by Ophiomorpha (Ichnocoenosis 1) frequently interfinger with fossil coral reefs.

Fossil Upogebia vasquezi burrows occurring in intertidal calcarenites (Ichnocoenosis 3) and Psilonichnus upsilon, most common in beach backshore beds (Ichnocoenosis 4), are valid indicators of sea-level position and have excellent potential as stratigraphic markers. Carbonate eolianites (Ichnocoenosis 5) exhibit the highest ichno-diversity owing to the presence of arthropodgenerated trace fossils and can be dominated by the presence of rhizomorphs, particularly in late Pleistocene, regressive dune sequences. Trace fossils representing the activities of insects, such as the large and complex cluster and stellate burrows and the small, irregular burrows, can impart distinctive ichnofabrics to eolianites, as well as offering unique perspectives on behavioral entomology of their tracemakers. The common occurrence of both animal and plant trace fossils in these carbonate eolianites should be noted by ichnologists and sedimentologists studying more ancient carbonates, particularly core samples. An eolian interpretation should not be ruled out based on the presence of trace fossils or an ichnofabric.

Ichnological studies of modern tropical carbonate environments and their rock-record equivalents are far from complete and have much potential for future development. Furthermore, ichnological information from carbonates should be combined with that from siliciclastics for a more complete understanding of depositional environments and the sedimentary rock record, and not viewed as a separate sub-discipline of ichnology.

\section{ACKNOWLEDGEMENTS}

I thank the directors and staff of the Gerace Research Center for support of my fieldwork on San Salvador for over two decades and for facilitating much of my work on other islands of the Bahamas. Brian White (Smith College), Tony Martin (Emory
University), Mark Wilson (The College of Wooster), Jim Carew (College of Charleston), and John Mylroie (Mississippi State University) contributed much to my thinking about Bahamian geology and ichnology through many spirited discussions over the years, and many Smith College geology students assisted with field studies. Bill Precht (PBS\& J Engineering) introduced me to several key Miami Limestone outcrops in Florida. Alicia Simonti (Smith College) assisted with preparation of figures, and Jen Christiansen (Smith College alumnus) drafted Fig. 14.2. Gabriela Mańgano and Elizabeth Nesbitt provided helpful critical reviews of an earlier version of this chapter. Finally, I thank William Miller III for his vision, hard work, and patience in organizing and editing this volume.

\section{References}

Berkenbusch, K. and Rowden, A.A. (2003). Ecosystem engineering moving away from 'just-so' stories. New Zealand Joumal of Ecology, 27, 67-73.

Bromley, R.G. (1996). Trace Fossils: Biology, Taphonomy and Applications, 2nd edition. Chapman \& Hall, London, $361 \mathrm{pp}$.

Buck, S.G. and Goldring, R. (2003). Conical sedimentary structures, trace fossils or not? Observations, experiments, and review. Jourmal of Sedimentary Petrology, 73, 338-353.

Carew, J.L. and Mylroie, J.E. (1995). Depositional model and stratigraphy for the Quaternary geology of the Bahama Islands. In: Curran, H.A. and White, B. (Eds.), Terrestrial and Shallow Marine Geology of the Bahamas and Bermuda, Geological Society of America, Boulder, Colorado, Special Paper, 300, pp. 5-32.

Carew, J.L. and Mylroie, J.E. (1997). Geology of the Bahamas. In: Vacher, H.L. and Quinn, T.M. (Eds.), Geology and Hydrogeology of Carbonate Islands, Developments in Sedimentology, Elsevier Science B.V., Amsterdam, 54, pp. 91-139.

Carew, J.L. and Mylroie, J.E. (2001). Quaternary carbonate eolianites of the Bahamas: useful analogues for the interpretation of ancient rocks? In: Abegg, F.E., Harris, P.M. and Loope, D.B. (Eds.), Modern and Ancient Carbonate Eolianites: Sedimentology, Sequence Stratigraphy, and Dingenesis, SEPM (Society for Sedimentary Geology), Tulsa, Oklahoma, Special Publication, 71, pp. 33-45.

Curran, H.A. (1994). The palaeobiology of ichnocoenoses in Quaternary, Bahamian-style carbonate environments: the modern to fossil transition. In: Donovan, S.K. (Ed.), Palaeobiology of Trace Fossils, John Wiley \& Sons, Ltd., Chichester, England, pp. 83-104.

Curran, H.A. (Ed.) (1997). Guide to Bahamian Ichnology: Pleistocene, Holocene, and Modern Environments, Bahamian Field Station, San Salvador, $61 \mathrm{pp}$.

Curran, H.A. and Martin, A.J. (2003). Complex decapod burrows and ecological relationships in modern and Pleistocene intertidal carbonate environments, San Salvador Island, Bahamas. Palaeogeography, Palaeoclimatology, Palaeoecology, 192, 229-245.

Curran, H.A. and White, B. (1991). Trace fossils of shallow subtidal to dunal ichnofacies in Bahamian Quaternary carbonates. Palaios, 6, 498-510. 
Curran, H.A. and White, B. (Eds.) (1995). Terrestrial and Shallow Marine Geology of the Bahamas and Bermuda, Geological Society of America, Boulder, Colorado, Special Paper, 300, $344 \mathrm{pp}$.

Curran, H.A. and White, B. (1997). A Conichms conicus-generated ichnofabric in the late Pleistocene limestones at Clifton Pier, New Providence Island, Bahamas. In: Curran, H.A. (Ed.), Guide to Bahamian Ichnology: Pleistocene, Holocene, and Modern Enviromments, Bahamian Field Station, San Salvador, pp. 55-61.

Curran, H.A. and White, B. (2001). Ichnology of Holocene carbonate eolianites of the Bahamas. In: Abegg, F.E., Harris, P.M. and Loope, D.B. (Eds.), Modern and Ancient Carbonate Eolianites: Sedimentology, Sequence Stratigraphy, and Dingenesis, SEPM (Society for Sedimentary Geology), Tulsa, Oklahoma, Special Publication, 71, pp. 47-56.

De, C. (2005). Biophysical model of intertidal beach crab burrowing: application and significance. Ichos, 12, 11-29.

Dworschak, P.C. (2000). Global diversity in the Thalassinidea (Decapoda). Journal of Crustacean Biology, Special Issue No. 2, $20,238-245$.

Dworschak, P.C. (2004). Biology of Mediterranean and Caribbean Thalassinidea (Decapoda). In: Tamaki, A. (Ed.), Proceedings of the Symposium on 'Ecology of Large Bioturbators in Tidal Flats and Shallow Sublittoral Sediments - from Itdividual Behavior to Their Role as Ecosystem Enginters', Nagasaki University, Nagasaki, Japan, pp. 15-22.

Dworschak, P.C. and Ott, J.A. (1993). Decapod burrows in mangrove-channel and back-reef environments at the Atlantic Barrier Reef, Belize. Ichnos, 2, 277-290.

Evans, C.C. and Ginsburg, R.N. (1987). Fabric-selected diagenesis in the late Pleistocene Miami Limestone. Joumal of Sedimentary Petrology, 57, 311-318.

Farrow, G.F. (1971). Back-reef and lagoonal environments of Aldabra Atoll distinguished by their crustacean burrows. In: Stoddart, D.R. and Yonge, M. (Eds.), Regional Variation in Indian Ocean Coral Reefs, Symposia Zoological Society of Lonton, Academic Press, London, 28, pp. 455-500.

Frey, R.W. and Pemberton, S.G. (1987). The Psilonichnus ichnocoenose, and its relationship to adjacent marine and nonmarine ichnocoenoses along the Georgia coast. Bulletin of Canadian Petroleum Geology, 35, 333-357.

Frey, R.W., Curran, H.A. and Pemberton, S.G. (1984). Tracemaking activities of crabs and their environmental significance: the ichnogenus Psilonichmus. Journal of Paleontology, 58, 333-350.

Garrett, P. (1977). Biological communities and their sedimentary record. In: Hardie, L.A. (Ed.), Sedimentation on the Modern Carbonate Tidal Flats of Northwest Andros Island, Bahamas, The Johns Hopkins University Studies in Geology, The Johns Hopkins University Press, Baltimore, No. 28, pp. 124-158.

Genise, J.F. (2000). The Ichnofamily Celliformidae for Celliforma and allied ichnogenera. Iclmos, 7, 267-282.

Halley, R.B. and Evans, C.G. (1983). The Miami Limestone: A Guide to Selected Outcrops and their Interpretation, Miami Geological Society, Miami, Florida, $67 \mathrm{pp}$.
The Johns Hopkins University Studies in Geology, No. 28. In: Hardie, L.A. (Ed.) (1977). Sedimentation of the Modern Carbonate Tidal Flats of Northwest Andros Island, Bahamas, The Johns Hopkins University studies in Geology, 15, The Johns Hopkins University Press, Baltimore, Maryland, $202 \mathrm{pp}$.

Jones, B. and Pemberton, S.G. (1989). Sedimentology and ichnology of a Pleistocene unconformity-bounded, shallowing-upward carbonate sequence: the Ironshore Formation, Salt Creek, Grand Cayman. Palaios, 4, 343-355.

Jones, C.G., Lawton, J.H. and Shachak, M. (1994). Organisms as ecosystem engineers. Oikos, 69, 373-386.

Mcllroy, D. (2004). Some ichnological concepts, methodologies, applications and frontiers. In: Mcllroy, D. (Ed.), The Application of Ichnology to Palaeoenvirommental and Stratigraphic Analysis, The Geological Society, London, Special Publication, 228, pp. 3-27.

Nesbitt, E.A. and Campbell, K.A. (2006). The ichnotaxonomy, ichnofacies and the paleoenvironmental significance of Psilonichnus. Palaios, 21, 187-196.

Pemberton, S.G. and Jones, B. (1988). Ichnology of the Pleistocene Ironshore Formation, Grand Cayman Island, British West Indies. Journal of Paleontology, 62, 495-505.

Pemberton, S.G., Spila, M., Pulham, A.J., Saunders, T., MacEachern, J.A., Robbins, D. and Sinclair, I.K. (2001). Ichnology \& Sedimentology of Shallow to Marginal Marine Systems: Bent Nevis \& Avalon Reservoirs, Jeame d'Arc Basin, 15, Geological Association of Canada, St. John's Newfoundland, Short Course Notes, $343 \mathrm{pp}$.

Randazzo, A.F. and Halley, R.B. (1997). Geology of the Florida Keys. In: Randazzo, A.F. and Jones, D.S. (Eds.), The Geology of Florida, University of Florida Press, Gainesville, pp. 251-259.

Shinn, E.A. (1968). Burrowing in Recent lime sediments of Florida and the Bahamas. Journal of Paleontology, 42, 879-894.

Tedesco, L.P. and Wanless, H.R. (1991). Generation of sedimentary fabrics and facies by repetitive excavation and storm infilling of burrow networks, Holocene of South Florida and Caicos Platform, B.W.I. Palaios, 6, 326-343.

Tudhope, A.W. and Scoffin, T.P. (1984). The effects of Callianassa bioturbation on the preservation of carbonate grains in Davies Reef Lagoon, Great Barrier Reef, Australia. Journal of Sedimentary Petrology, 54, 1091-1096.

Vacher, H.L. and Quinn, T.M. (Eds.) (1997). Geology and Hydrogeology of Carbonate Islands, Developnents in Sedimentology, Elsevier Science B.V., Amsterdam, 54, 948 pp.

Walker, S.E., Holland, S.M. and Gardiner, L. (2003). Coenobichnus currani (new ichnogenus and ichnospecies): fossil trackway of a land hermit crab, early Holocene, San Salvador, Bahamas. Journal of Paleontology, 77, 576-582.

White, B. and Curran, H.A. (1988). Mesoscale physical sedimentary structures and trace fossils in Holocene carbonate eolianites from San Salvador Island, Bahamas. Sedimentary Geology, 55, 163-184. 